\title{
Polylactic Acid (PLA) Foaming: Design of Experiments for Cell Size Control
}

\author{
Miada Abubaker Osman1,2, Nick Virgilio',3, Mahmoud Rouabhia ${ }^{1,4}$, Frej Mighri1,2* \\ ${ }^{1}$ Research Center for High Performance Polymer and Composite Systems, CREPEC, Montreal, Canada \\ ${ }^{2}$ Department of Chemical Engineering, Faculty of Science and Engineering, Laval University, Quebec, Canada \\ ${ }^{3}$ Department of Chemical Engineering, Polytechnique Montreal, Montreal, Canada \\ ${ }^{4}$ Faculty of Dentistry, Laval University, Quebec, Canada \\ Email: ^frej.mighri@gch.ulaval.ca
}

How to cite this paper: Osman, M.A., Virgilio, N., Rouabhia, M. and Mighri, F. (2022) Polylactic Acid (PLA) Foaming: Design of Experiments for Cell Size Control. Materials Sciences and Applications, 13, 63-77.

https://doi.org/10.4236/msa.2022.132005

Received: Jnauary 8, 2022

Accepted: February 19, 2022

Published: February 22, 2022

Copyright (C) 2022 by author(s) and Scientific Research Publishing Inc. This work is licensed under the Creative Commons Attribution International License (CC BY 4.0)

http://creativecommons.org/licenses/by/4.0/

\begin{abstract}
In this study, a design of experiments (DoE) approach was used to develop a PLA open-cell foam morphology using the compression molding technique. The effect of three molding parameters (foaming time, mold opening temperature, and weight concentration of the ADA blowing agent) on the cellular structure was investigated. A regression equation relating the average cell size to the above three processing parameters was developed from the DoE and the analysis of variance (ANOVA) was used to find the best dimensional fitting parameters based on the experimental data. With the help of the DoE technique, we were able to develop various foam morphologies having different average cell size distribution levels, which is important in the development of open-cell PLA scaffolds for bone regeneration for which the control of cell morphology is crucial for osteoblasts proliferation. For example, at a constant ADA weight concentration of $5.95 \mathrm{wt} \%$, we were able to develop a narrow average cell size distribution ranging between 275 and $300 \mu \mathrm{m}$ by varying the mold opening temperature between $106^{\circ} \mathrm{C}$ and $112^{\circ} \mathrm{C}$, while maintaining the foaming time constant at $8 \mathrm{~min}$, or by varying the mold foaming time between 6 and $11 \mathrm{~min}$ and maintaining the mold opening temperature at $109^{\circ} \mathrm{C}$.
\end{abstract}

\section{Keywords}

PLA, Open-Cell Foam, Design of Experiments, Cell Size Distribution

\section{Introduction}

Polymer foams are found everywhere in our modern world daily life since they are used in different applications such as cushioning, insulation material [1], and 
biomedical applications as scaffolds in tissue engineering [2]. A polymer foam is typically obtained from a polymer and gas mixture, which gives the polymer a cellular structure (open-cell or closed-cell) with the desired thermal, mechanical, and/or acoustic properties. In addition, it causes the polymer to have a lower density. There are several methods to produce polymer foams, such as injection or compression molding, and extrusion. Polymer foams are either based on thermoplastics or thermosets; the main difference being that the first ones can be reprocessed, while the second ones cannot [1]. For all the foaming processes (extrusion, injection, or compression molding) using chemical foaming agents, the selection of the latter is based on a general rule of thumb. Its decomposition temperature should be relatively close to the polymer processing temperature, and the released gas should not chemically react with the polymer [3].

Recently, research has focused on the partial substitution of petrochemical-based polymers with biobased ones due to safety (non-toxicity), environmental, and economic challenges [4]. Polylactic acid (PLA) is one of the main biobased thermoplastic polymers due to its good processability and its high strength and modulus [5]. It is presently considered as one of the main biomaterials and is largely used in industrial packaging, biocompatible/bioabsorbable medical devices, and as a replacement of regular petrochemical-based polymers for many industrial applications [5] [6]. PLA is obtained from lactic acid (LA), which is an organic acid produced from renewable non-toxic raw materials [7] [8]. Corn starch or sugarcane are examples of the renewable resources from which LA can be obtained by fermentation [9] [10]. As a result, PLA is classified as an eco-friendly material, is considered to be biocompatible with the human body (nontoxicity), and is presently classified by the United States Food and Drug Administration (FDA) as a safe biomaterial (GRAS) [4]. This has led to more research activities, especially in the biomedical sector [11] [12] [13].

There are many advantages of PLA compared to other biopolymers [4]: 1) its biocompatibility is particularly attractive for biomedical applications. A biocompatible material must not generate carcinogenic or toxic effects in local tissues, and the products coming from its degradation should not interfere with the healing tissue. When a PLA scaffold is implanted in living organisms, it hydrolyzes to its constituent $\alpha$-hydroxy acid, then combines into the tricarboxylic acid cycle, and is finally eliminated from the organism [13]; 2) PLA is an eco-friendly material since it is synthesized from renewable resources (e.g., wheat, corn, or rice). It is also recyclable, biodegradable, and compostable [5] [14]; 3) PLA presents a good thermal processability, compared to many other biopolymers [15]; 4) Finally, the production of PLA needs $25 \%$ to $55 \%$ less energy compared to petroleum-based polymers [13].

The main objective of this study is to design, by compression molding, an open-cell PLA foam scaffold for bone and cartilage regeneration. Research presented in this article is a first part of a broader study and focuses only on the effect of the processing parameters on cell morphology and cell size distribution of the developed foams. This will be essential in the second part of the project, 
where a biocompatible PLA-based open cell scaffold with a tailored cell size and narrow cell size distribution will be designed. So, the originality of the present work is the obtention of adequate sets of optimised processing parameters needed for the design of different levels of narrow cell size distributions needed for cells proliferation, such as bone or cartilage cells.

To do this, a three-level factorial Design of Experiments (DoE) based on the response surface method (RSM) [16] is used to investigate the influence of three foaming process parameters (foaming time, mold opening temperature, and the blowing agent weight concentration) and their interactions on the average cell size of the developed foamed scaffolds. The main purpose of the DoE is the selection of the experimental conditions and the evaluation of their corresponding responses. A polynomial mathematical model representing the process is then constructed to find the optimal design [17]. The Central Composite Design (CCD) sketched in Figure 1 is a type of RSM technique that is used to find the minimum number of experiments that should be evaluated to optimize the variables and their corresponding responses. The eight black corners of the cube correspond to the factorial points, while the six white circles correspond to the axial points. As shown in Figure 1, if the distance from the center of the design space to a factorial point is \pm 1 unit for each factor, the distance $\alpha \quad(|\alpha|>1)$ from the center of the design space to an axial point can be found with the following Equation (1) [18]:

$$
\alpha=\left(n_{f}\right)^{1 / 4}
$$

For a three-level factorial DoE, eight factorial points $\left(n_{f}=2^{3}=8\right)$, six axial points $(2 \times 3)$ and six centre runs, a total of 20 experimental runs can be considered. Generally, these experimental runs are conducted in random order [18], [19]. The value of $\alpha$ in Equation (1) is then calculated ( $\alpha=8^{1 / 4}=1.682$ ).

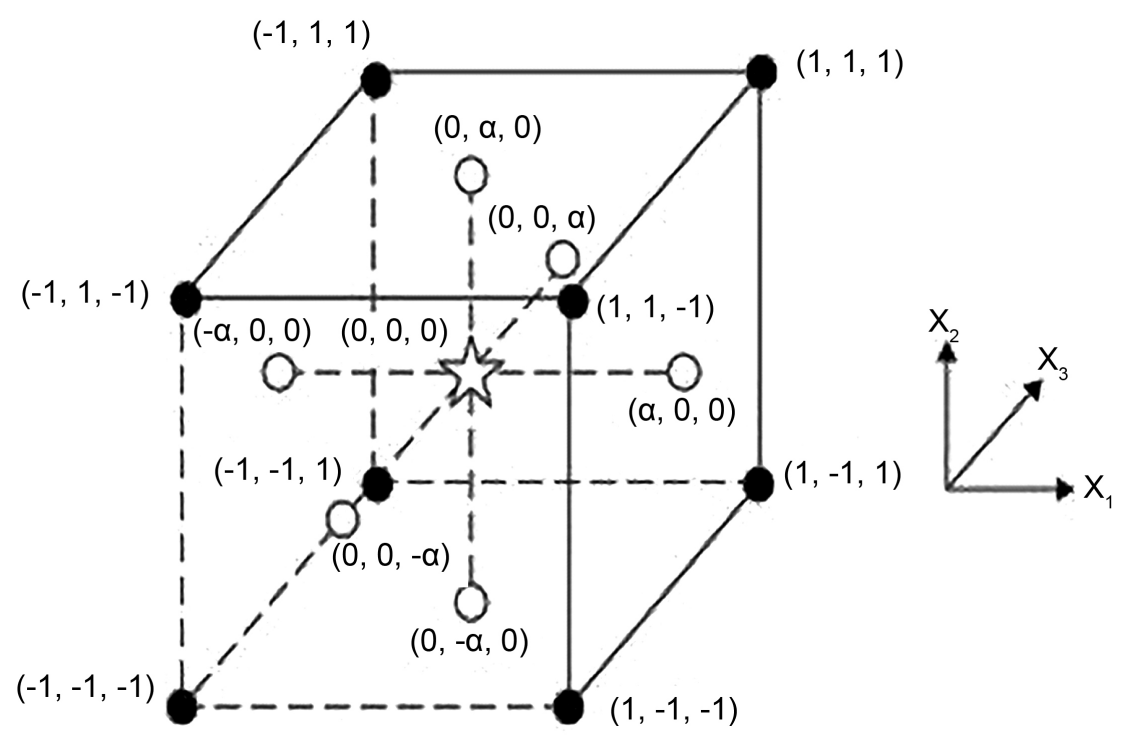

Figure 1. Central composite design, CCD, with three factors, $X_{1}, X_{2}$ and $X_{3}$ [18]. 
The appropriate low-level $(-1)$ and high-level $(+1)$ settings of each variable for the "cube" are calculated as follows:

$$
\left\{\begin{array}{l}
\operatorname{Low}-\operatorname{level}(-1)=\left((\alpha-1) V_{\text {max }}+(\alpha+1) V_{\text {min }}\right) / 2 \alpha \\
\operatorname{High-level}(+1)=\left((\alpha-1) V_{\text {min }}+(\alpha+1) V_{\text {max }}\right) / 2 \alpha
\end{array}\right.
$$

where $V_{\min }$ and $V_{\max }$ are respectively the minimum and maximum levels of the process parameters studied.

\section{Materials and Methodology}

\subsection{Materials}

Polylactide (PLA) (Ingeo biopolymer 2003D, $4.3 \mathrm{~mol} \%$ D-lactide content, specific gravity: 1.24 , tensile strength: $53 \mathrm{MPa}$, melting temperature: $151^{\circ} \mathrm{C}$ ) was purchased from NatureWorks, USA. Azodicarbonamide (ADA, CELOGEN $754 \mathrm{~A}$, density: $1.68 \mathrm{~g} / \mathrm{cm}^{3}$ at $25^{\circ} \mathrm{C}$, decomposition temperature: $164^{\circ} \mathrm{C}-180^{\circ} \mathrm{C}$ ) was purchased from CelChem, USA.

\subsection{Sample Preparation and Foaming Process}

First, PLA was dried under vacuum for $12 \mathrm{~h}$ at $50^{\circ} \mathrm{C}$ using a Shel Lab oven, model 1445. Then, it was mixed for 3 min with ADA added at different weight concentrations (see Table 1), using a Hamilton Beach Single-Serve Blender (model 51101BZ). The PLA/ADA mixture was then placed into the mold cavity $(0.3 \mathrm{~cm} \times 6 \mathrm{~cm} \times 6 \mathrm{~cm})$ placed between the plates of an automatic compression press (Carver, Model: Auto series 3893). For all of the samples, the compressing pressure was maintained constant at $12 \mathrm{MPa}$ and the compression (foaming) time was varied from 5 to $15 \mathrm{~min}$, depending on the experiment, as shown in Table 2. Foamed PLA samples were then obtained by reducing the temperature of the mold to the mold opening temperature (values are shown in Table 1). Finally, the mold was opened, and the foamed sample was cooled down to room temperature. Scheme 1 shows a sketch of the different steps of the foaming process.

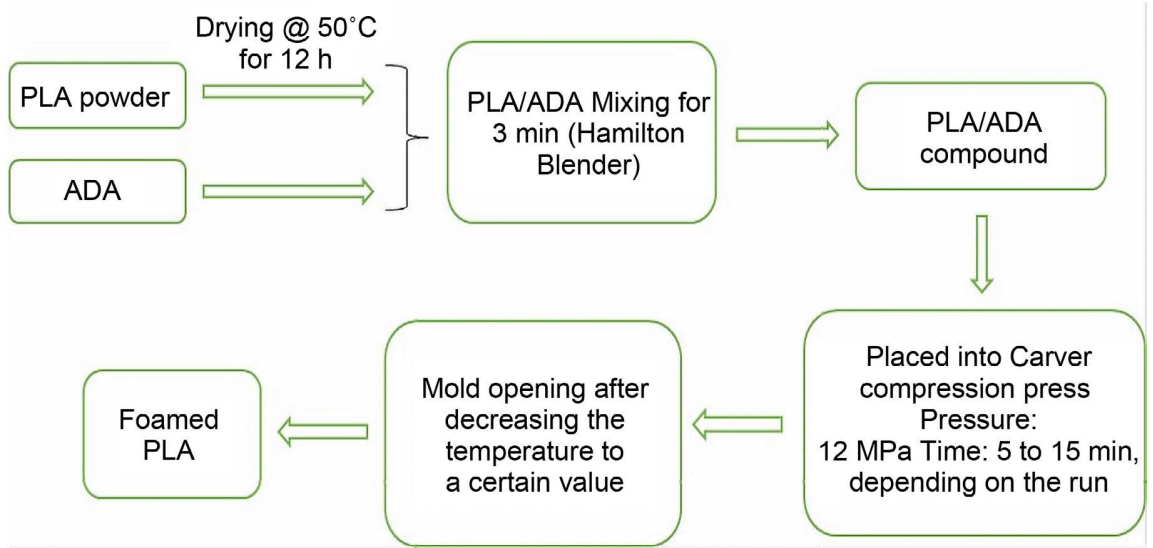

Scheme 1. Sketch of the different steps for the preparation of PLA foams. 
Table 1. The three independent foaming parameters (foaming time, mold opening temperature, blowing agent concentration) and their corresponding levels obtained by the CCD technique.

\begin{tabular}{|c|c|c|c|c|c|c|c|c|}
\hline \multirow[t]{2}{*}{ Factors } & \multirow[t]{2}{*}{ Tag } & \multirow[t]{2}{*}{ Symbol } & \multirow[t]{2}{*}{ Units } & \multicolumn{5}{|c|}{ Levels } \\
\hline & & & & $-a$ & -1 & 0 & 1 & $+\alpha$ \\
\hline Foaming time & $\mathrm{t}$ & $X_{1}$ & $\min$ & 5 & 7.03 & 10 & 12.97 & 15 \\
\hline $\begin{array}{c}\text { Mold opening } \\
\text { temperature }\end{array}$ & $\mathrm{T}$ & $X_{2}$ & ${ }^{\circ} \mathrm{C}$ & 80 & 88.1 & 100 & 111.9 & 120 \\
\hline $\begin{array}{l}\text { ADA blowing } \\
\text { agent weight } \\
\text { concentration }\end{array}$ & IC & $X_{3}$ & $\mathrm{Wt} \%$ & 4.20 & 4.91 & 5.95 & 6.99 & 7.70 \\
\hline
\end{tabular}

Table 2. Randomization of the independent factors for $X_{1}, X_{2}$, and $X_{3}$ in experimental runs and their corresponding average cell size.

\begin{tabular}{|c|c|c|c|c|c|c|}
\hline $\begin{array}{c}\text { Run } \\
\text { number }\end{array}$ & $\begin{array}{c}\text { Factor } \\
\text { for } \\
X_{1}\end{array}$ & $\begin{array}{c}\text { Factor } \\
\text { for } \\
X_{2}\end{array}$ & $\begin{array}{c}\text { Factor } \\
\text { for } \\
X_{3}\end{array}$ & $\begin{array}{c}\text { Average } \\
\text { cell size } \\
(\mu \mathrm{m})\end{array}$ & $\begin{array}{c}\text { Average } \\
\text { cell size } \\
\text { standard } \\
\text { deviation } \\
\quad(\mu \mathrm{m})\end{array}$ & $\begin{array}{c}\text { Coefficient } \\
\text { of } \\
\text { variation, } \\
\mathrm{CV}= \\
\text { (Standard } \\
\text { deviation/ } \\
\text { average cell } \\
\text { size) }\end{array}$ \\
\hline 1 & 0 & 0 & 0 & 287 & 41 & 0.140 \\
\hline 2 & 0 & 0 & $-\alpha$ & 194 & 39 & 0.200 \\
\hline 3 & +1 & +1 & -1 & 311 & 6 & 0.019 \\
\hline 4 & +1 & -1 & +1 & 289 & 17 & 0.059 \\
\hline 5 & +1 & +1 & +1 & 368 & 25 & 0.068 \\
\hline 6 & 0 & $+\alpha$ & 0 & 326 & 49 & 0.150 \\
\hline 7 & 0 & 0 & 0 & 276 & 31 & 0.110 \\
\hline 8 & $-\alpha$ & 0 & 0 & 209 & 19.5 & 0.093 \\
\hline 9 & $+\alpha$ & 0 & 0 & 294 & 19 & 0.065 \\
\hline 10 & -1 & -1 & +1 & 254 & 25 & 0.098 \\
\hline 11 & 0 & $-\alpha$ & 0 & 136 & 19 & 0.140 \\
\hline 12 & 0 & 0 & 0 & 232 & 12 & 0.052 \\
\hline 13 & -1 & -1 & -1 & 84 & 5 & 0.060 \\
\hline 14 & 0 & 0 & $\alpha$ & 317 & 12 & 0.038 \\
\hline 15 & -1 & +1 & +1 & 323 & 16 & 0.050 \\
\hline 16 & 0 & 0 & 0 & 251 & 35 & 0.140 \\
\hline 17 & -1 & +1 & -1 & 278 & 49 & 0.176 \\
\hline 18 & +1 & -1 & -1 & 233 & 62 & 0.266 \\
\hline 19 & 0 & 0 & 0 & 283 & 39 & 0.140 \\
\hline 20 & 0 & 0 & 0 & 262 & 24 & 0.092 \\
\hline
\end{tabular}




\subsection{Foam Cell Measurement}

PLA foam samples were first frozen in liquid nitrogen to ensure a brittle fracture [19]. Magnified pictures of the fractured surfaces were then acquired using a stereomicroscope (Model: SZ-PT 126x) and the average cell size was obtained using the image processing, Image J, software (at least three measurements per cell were done and their average value is reported). The final average cell size was calculated from the results of at least three different samples for each run.

\section{Results and Discussion}

\subsection{Determination of the Three Levels of the Processing Parameters: Foaming Time, Mold Opening Temperature, and ADA Blowing Agent Concentration}

The central composite design (CCD) technique was used in this work to design the three levels (low-level: -1 , mid-level: 0 , and high-level: +1 ) of the three independent processing parameters shown in Table 1, which are the foaming time under compression, $X_{1}(\mathrm{~min})$, the mold opening temperature, $X_{2}\left({ }^{\circ} \mathrm{C}\right)$, and the ADA blowing agent weight concentration, $X_{3}(\mathrm{wt} \%)$. The mold opening temperature is the temperature at which the mold is opened following a rapid cooling upon the end of the foaming time.

As reported in literature, the decomposition temperature of $\mathrm{ADA}$ is between $165^{\circ} \mathrm{C}$ and $180^{\circ} \mathrm{C}$ [20], and the melting temperature of PLA is $150^{\circ} \mathrm{C}$ [21]. Using $\mathrm{ADA}$ as a foaming agent, Luo, Zhang, Qi, $\mathrm{Lu}, \mathrm{Hu}$ and Jiang [21] reported that the optimum foaming temperature for PLA is $180^{\circ} \mathrm{C}$ during a foaming time under compression of $10 \mathrm{~min}$. Based on this study, the foaming temperature was maintained constant at $180^{\circ} \mathrm{C}$ and the foaming time $X_{1}(\mathrm{~min})$ was considered as an independent parameter for cell size optimization. Its minimum and maximum limits were taken at equal intervals from the foaming time of 10 min used by the above authors ( $X_{1 \min }=5 \mathrm{~min}, X_{1 \max }=15 \mathrm{~min}$ ).

To get an adequate foam, the mold must be cooled quickly after PLA foaming to increase the PLA viscosity and consequently avoid cell collapse. Mold opening should be performed at a temperature that is between the glass transition temperature $\left(T_{g}\right)$ and the melting temperature of PLA, which are $58^{\circ} \mathrm{C}$ and $151^{\circ} \mathrm{C}$, respectively [21]. It was found that when the mold opening temperature was higher than $120^{\circ} \mathrm{C}$, bubbles were ruptured due to the low PLA viscosity; on the other hand, when the temperature was lower than $80^{\circ} \mathrm{C}$, not enough bubbles were formed. Based on these observations, the mold opening temperature was set between $X_{2 \min }=80^{\circ} \mathrm{C}$ and $X_{2 \max }=120^{\circ} \mathrm{C}$ for cell optimization.

To study the effect of the ADA blowing agent concentration on the average cell size, preliminary tests were performed at $180^{\circ} \mathrm{C}$ to determine the minimum and maximum ADA concentrations needed to obtain a foam with an open-cell structure. For a mold opening temperature of $100^{\circ} \mathrm{C}$ and a foaming time of 10 min, the ADA concentration was slowly increased until the formation of an open cell structure, which was obtained at $4.2 \mathrm{wt} \%$ ADA. On the other hand, 
foam collapse was observed for ADA weigh concentrations higher than $7.7 \mathrm{wt} \%$. Based on these results, the ADA concentration was set between $4.2 \mathrm{wt} \%$ and 7.7 wt $\%$.

Knowing the minimum and maximum values of the three independent parameters $X_{1}, X_{2}$ and $X_{3}$, the calculation of their corresponding low-level $(-1)$, mid-level (0), and high-level $(+1)$ values is done using the CCD technique (Figure 1) and the corresponding values are shown in Table 1. As an example, the following steps show how to find the corresponding values for the foaming time, $X_{1}$ (min): 1) First, the minimum and maximum values of $X_{1}$ corresponding to $-\alpha$ and $+\alpha$ are respectively $5 \mathrm{~min}$ and $15 \mathrm{~min}$, as mentioned above in this section; 2 ) the mid-level (0), which is the center between $-\alpha$ and $+\alpha$, is then equal to $(5+15) / 2=10 \mathrm{~min} ; 3)$ Equation (2) is then used to get the low and high level settings of $X_{1}$, which are respectively:

$\left\{\begin{array}{l}\text { Low-level }(-1)=((1.682-1) \times 15 \mathrm{~min}+(1.682+1) \times 5 \mathrm{~min}) /(2 \times 1.682)=7.03 \mathrm{~min} \\ \text { High-level }(+1)=((1.682-1) \times 5 \mathrm{~min}+(1.682+1) \times 15 \mathrm{~min}) /(2 \times 1.682)=12.97 \mathrm{~min}\end{array}\right.$

The low, mid, and high levels for $X_{2}$ and $X_{3}$ are calculated in the same manner and their corresponding values are shown in Table 1.

\subsection{Effect of the Foaming Time, Mold Opening Temperature, and ADA Blowing Agent Concentration on the Average Cell Size}

Figures 2(a)-(c) show SEM micrographs corresponding to foamed samples respectively obtained from the runs 11, 1 and 6, presented below in Table 2. Their corresponding foaming time and blowing agent concentration were kept constant at $10 \mathrm{~min}$ and $5.95 \mathrm{wt} \%$ and their mold opening temperature was varied [80 ${ }^{\circ} \mathrm{C}$ (level: $-\alpha$ ) (Figure $2(\mathrm{a})$ ), $100^{\circ} \mathrm{C}$ (level: 0 ) (Figure $2(\mathrm{~b})$ ), and $120^{\circ} \mathrm{C}$ (level: $+\alpha)$ (Figure 2(c))]. As shown, closed cell structure was obtained under a mold opening temperature of $80^{\circ} \mathrm{C}$ and larger cells were obtained with increasing the mold opening temperature, leading to an open cell structure at $120^{\circ} \mathrm{C}$. The corresponding results are presented in Table 2 and Figure 3(a). An increase of the mold opening temperature from $80^{\circ} \mathrm{C}$ to $120^{\circ} \mathrm{C}$ is accompanied by a respective increase in the average cell size from $136 \mu \mathrm{m}$ to $326 \mu \mathrm{m}$. Because of PLA matrix viscosity decrease and gas diffusion increase inside the PLA matrix with increasing the temperature, this leads to an increase in the formation and growth
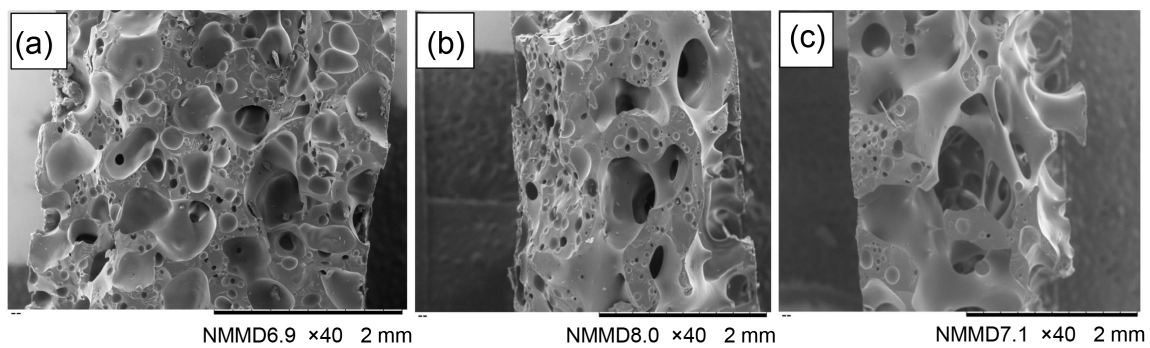

Figure 2. SEM micrographs of PLA foams. Effect of mold opening temperature, $X_{2}\left({ }^{\circ} \mathrm{C}\right)$ : (a) $80^{\circ} \mathrm{C}$, (b) $100^{\circ} \mathrm{C}$, and (c) $120^{\circ} \mathrm{C}$. 

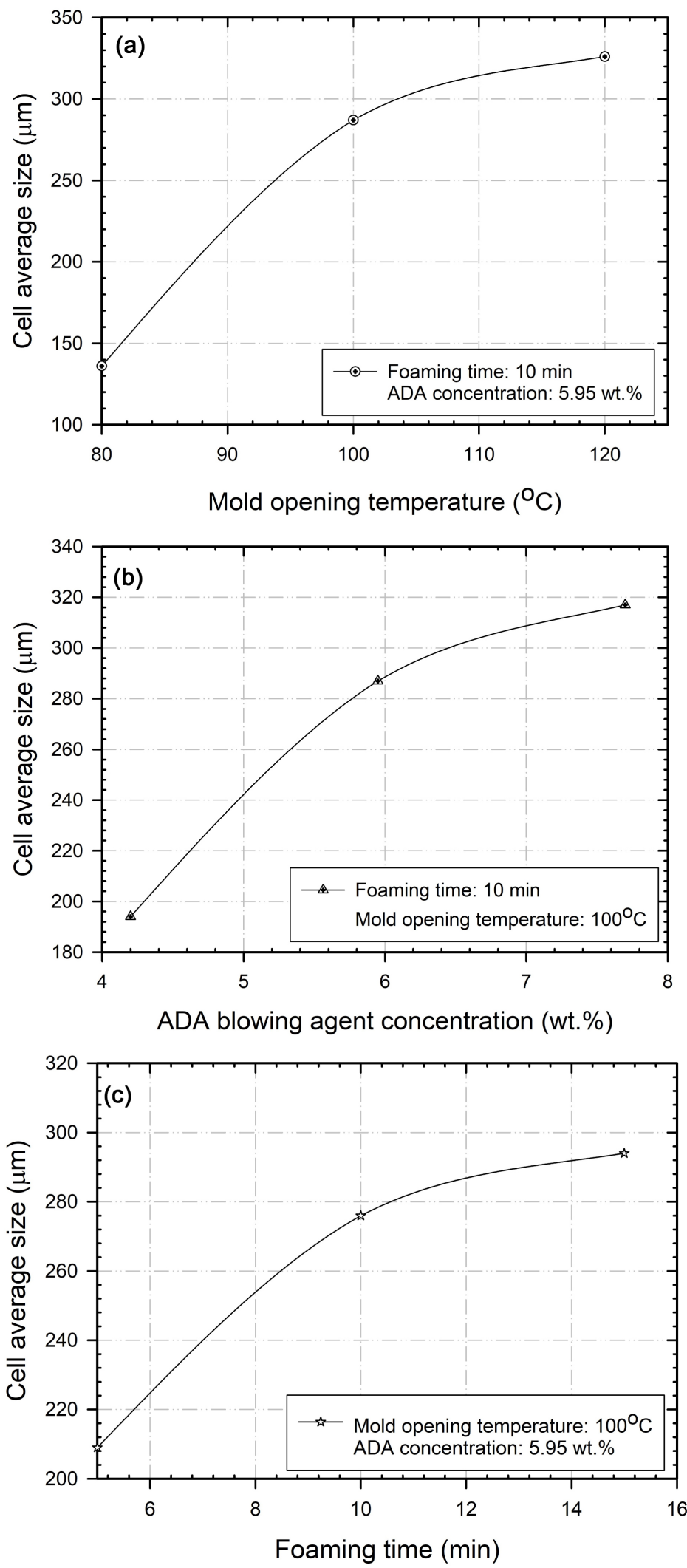

Figure 3. Average cell size $(\mu \mathrm{m})$ as a function of: (a) mold opening temperature $\left({ }^{\circ} \mathrm{C}\right)$, (b) ADA blowing agent weight concentration (wt\%), and (c) foaming time (min). 
of bubbles [21].

Keeping the foaming time and mold opening temperature constant at $10 \mathrm{~min}$ and $100^{\circ} \mathrm{C}$, respectively, the ADA weight concentration was varied from $4.2 \mathrm{wt} \%$ to $7.7 \mathrm{wt} \%$ and the corresponding results are presented in Table 2 (runs 1, 2, and 14) and Figure 3(b). The results show that an increase in ADA concentration is accompanied by an increase in cell size due to the higher gas concentration/amount generated inside the PLA matrix during ADA degradation, [21].

The effect of the foaming time on the average cell size was studied under a constant mold opening temperature $\left(T=100^{\circ} \mathrm{C}\right)$ and ADA concentration (5.95 wt\%) (i.e., $X_{2}$ and $X_{3}=0$ : runs 8, 9, 7). As shown in Figure 3(c), an increase of the foaming time from $5 \mathrm{~min}$ to $15 \mathrm{~min}$ leads to a respective increase of the average cell size from $209 \mu \mathrm{m}$ to $294 \mu \mathrm{m}$. This is because there is enough time for the generated smaller bubbles to expand and in many cases meet each other due to the high pressure gases [22].

\subsection{Statistical Analysis and Equation Relating the Average Cell Size to the Foaming Time, Mold Opening Temperature and Foaming Agent Weight Concentration}

The Minitab 17.0 software was used to randomize the 20 experimental runs shown in Table 2, and the polynomial model used by the software for the calculation of the cells average size, $Y$, as a function of the three significant factors $X_{1}$, $X_{2}$, and $X_{3}$, and their combinations, is given by Equation (3):

$$
\begin{aligned}
Y= & a+b \times X_{1}+c \times X_{2}+d \times X_{3}+e \times\left(X_{1} \times X_{1}\right)+f \times\left(X_{2} \times X_{2}\right) \\
& +g \times\left(X_{3} \times X_{3}\right)+h \times\left(X_{1} \times X_{2}\right)+i \times\left(X_{1} \times X_{3}\right)+j \times\left(X_{2} \times X_{3}\right)
\end{aligned}
$$

where the parameters $a$ to $j$ are adimensional fitting parameters.

The coefficient of variation (CV) shown in Table 2, which is the ratio between the standard deviation and the average cell size, gives an indication about the level of dispersion around the average cell size. Lower CV means a lower level of dispersion around the average cell size. Distributions with a coefficient of variation (CV) less than 1 are considered to be low-variance distributions, whereas those with a CV higher than 1.0 are considered to be high-variance distributions [23].

The analysis of variance (ANOVA) was used to find the best dimensional fitting parameters a to $j$ of Equation (2), based on the experimental data of Table 2 obtained for the 20 experimental runs. The final form of this equation with the calculated fitting parameters is as follows (Equation (4)):

$$
\begin{aligned}
Y= & -2352+72.2 \times X_{1}+26.1 \times X_{2}+189 \times X_{3}-0.006 \times\left(X_{1} \times X_{1}\right) \\
& -0.0515 \times\left(X_{2} \times X_{2}\right)+1.26 \times\left(X_{3} \times X_{3}\right)-0.375 \times\left(X_{1} \times X_{2}\right) \\
& -4.13 \times\left(X_{1} \times X_{3}\right)-1.252 \times\left(X_{2} \times X_{3}\right)
\end{aligned}
$$

The statistical significance of the fitting parameters of the above regression model used to estimate the average cell size was based on their probability values (P-values) presented in Table 3. These P-values indicate if the regression model 
Table 3. The P-values corresponding to the regression model (Equation (4)).

\begin{tabular}{|c|c|}
\hline Source & P-Value \\
\hline \multicolumn{2}{|c|}{ Linear interactions } \\
\hline$X_{1}$ & 0.001 \\
\hline$X_{2}$ & 0.000 \\
\hline$X_{3}$ & 0.000 \\
\hline \multicolumn{2}{|c|}{ Square interactions } \\
\hline$X_{1} * X_{1}$ & 0.993 \\
\hline$X_{2} * X_{2}$ & 0.291 \\
\hline$X_{3} * X_{3}$ & 0.839 \\
\hline \multicolumn{2}{|c|}{ 2-Way Interaction } \\
\hline$X_{1} * X_{2}$ & 0.162 \\
\hline$X_{1} * X_{3}$ & 0.177 \\
\hline$X_{2} * X_{3}$ & 0.108 \\
\hline Lack-of-Fit & 0.273 \\
\hline
\end{tabular}

fails to sufficiently describe the functional relationship between the average cell size and the three studied parameters (foaming time, $X_{1}$, mold opening temperature, $X_{2}$, and ADA blowing agent concentration, $X_{3}$ ). The fitting parameters are considered significant if their corresponding P-values are less than 0.05 , and not significant if their P-values are greater than 0.05 [24]. As shown in Table 3, the P-values corresponding to the linear interaction between the cell size $(Y)$ and the foaming process parameters $X_{1}, X_{2}$, and $X_{3}$ were all significant(their corresponding $\mathrm{p}$-values are less than 0.05$)$. However, their corresponding square and 2-way interactions were insignificant (corresponding $\mathrm{P}$-values where higher than 0.05). Finally, the P-value for the lack of fit was 0.273 (i.e., higher than 0.05), which means that there is no lack of fit and the regression model sufficiently describes the functional relationship between the average cell size $(Y)$ and the independent processing parameters $X_{1}, X_{2}$, and $X_{3}$.

The regression analysis of the 20 runs presented in Table 2 also provides various residual plots and two of them are shown in Figure 4 (the normal probability plot, Figure 4(a), and the residuals versus associated fitted values, Figure 4(b)). The normal probability plot of the residuals displays the residuals versus their expected values when the distribution is normal. Ideally, this plot should approximately follow a diagonal straight line (fitted values). Figure 4(a) clearly shows a normal distribution of the residuals. The difference between the observed values (round symbols) and their corresponding diagonal fitted values (continuous line), is relatively small. On the other hand, the residuals should ideally fall randomly around the center (zero) line, which is the case, as shown in Figure $4(\mathrm{~b})$. This indicates a high degree of correlation between the observed and predicted residual values. 

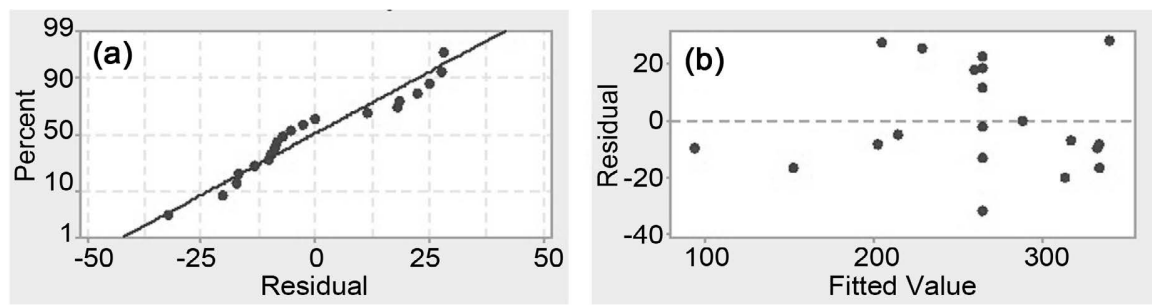

Figure 4. Residual plots for the average cell size from the 20 experimental runs: (a) normal probability plot; (b) residual versus fitted value (average cell size, $Y$ ).

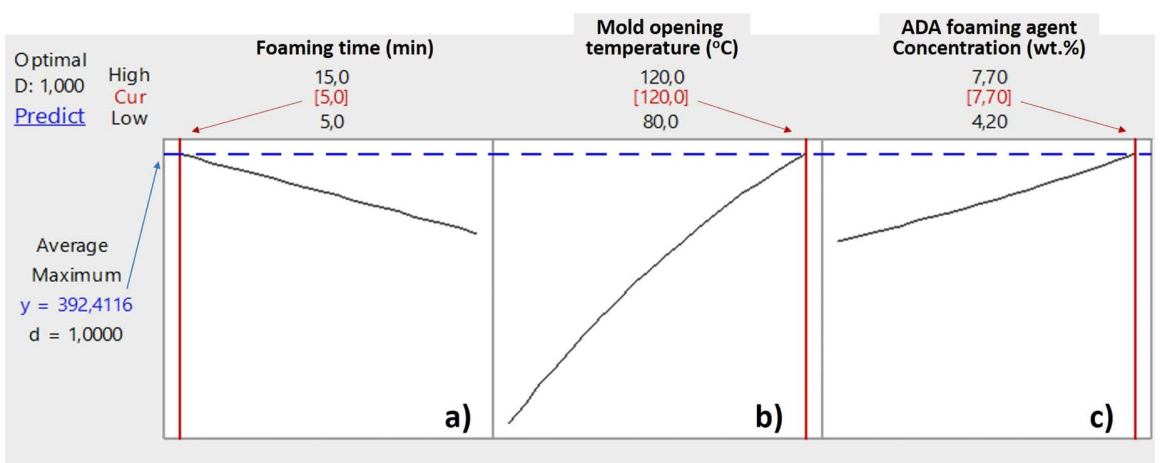

Figure 5. Minitab optimization curves for average cell size maximisation.

Figure 5 shows the optimization curves for the average cell size maximization (i.e., the maximization of the response $Y$ ) obtained using the "response optimizer" in the Minitab software. To do this, the three independent parameters $X_{1}, X_{2}$ and $X_{3}$ were respectively varied from 5 to $15 \mathrm{~min}$ (Figure $5(\mathrm{a})$ ), $80^{\circ} \mathrm{C}$ to $120^{\circ} \mathrm{C}$ (Figure 5(b)), and 4.2 to $7.7 \mathrm{wt} \%$ (Figure 5(c)). As shown, the maximum average cell size of $392.4 \mu \mathrm{m}$ was obtained at a foaming time of $5 \mathrm{~min}$, and a mold opening temperature of $120^{\circ} \mathrm{C}$.

Figure 6 presents the contour plots showing the evolution of the average cell size $(\mu \mathrm{m})$ with the variation of two of the three independent processing parameters, while maintaining the third one constant. Figure 6(a) shows that, for a constant ADA weight concentration of $5.95 \mathrm{wt} \%$, the average cell size increases from $125 \mu \mathrm{m}$ to about $375 \mu \mathrm{m}$ with increasing the foaming time from $5 \mathrm{~min}$ to 15 min (X-axis) and the mold opening temperature from $80^{\circ} \mathrm{C}$ to $120^{\circ} \mathrm{C}$ (Y-axis). So, the average cell size can be tailored by varying one or both of the two processing parameters, mold opening temperature or the foaming time. For example, a narrow average cell size ranging between 275 and $300 \mu \mathrm{m}$ can be obtained under a foaming time of $8 \mathrm{~min}$ and a mold opening time ranging between $106^{\circ} \mathrm{C}$ and $112^{\circ} \mathrm{C}$, or a mold opening temperature of $109^{\circ} \mathrm{C}$ and a foaming time ranging between 6 and $11 \mathrm{~min}$. Figure $6(\mathrm{~b})$ shows that, for a foaming time maintained constant at $10 \mathrm{~min}$, the average cell size increases from $100 \mu \mathrm{m}$ to about $400 \mu \mathrm{m}$ with increasing the mold opening temperature from $80^{\circ} \mathrm{C}$ to $120^{\circ} \mathrm{C}$ (X-axis) and the ADA weight concentration from $4.2 \mathrm{wt} \%$ to $7.7 \mathrm{wt} \%$ (Y-axis). So, a narrow average cell size ranging between 275 and $300 \mu \mathrm{m}$ can be obtained using $7.0 \mathrm{wt} \%$ ADA and a mold opening time ranging between 91 and 

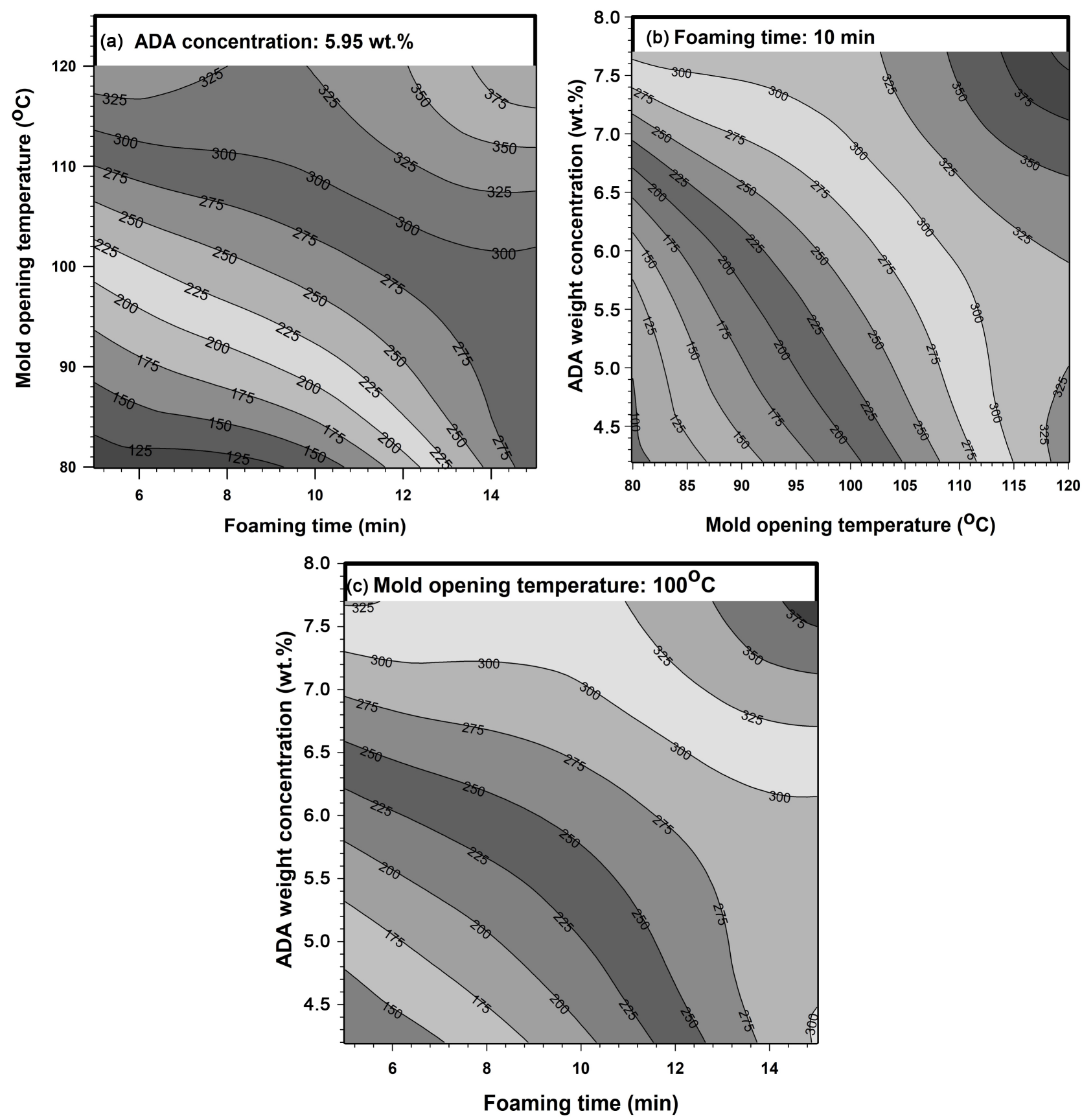

Figure 6. Contour plots of the average cell size $(\mu \mathrm{m})$ as a function of: (a) mold opening temperature $\left({ }^{\circ} \mathrm{C}\right)$ and foaming time (min) with ADA blowing agent concentration set constant at $5.95 \mathrm{wt} \%$, (b) ADA blowing agent concentration (wt\%) and mold opening temperature $\left({ }^{\circ} \mathrm{C}\right.$ ) with a foaming time set constant at $10 \mathrm{~min}$, and (c) ADA blowing agent concentration (wt\%) and foaming time (min) with a mold opening temperature set constant at $100^{\circ} \mathrm{C}$.

$101^{\circ} \mathrm{C}$. Finally, Figure $6(\mathrm{c})$ shows that, at a constant mold opening temperature of $100^{\circ} \mathrm{C}$, the average cell size varied from $150 \mu \mathrm{m}$ to about $375 \mu \mathrm{m}$ with increasing the foaming time from 5 min to 15 min (X-axis) and ADA concentration from $4.2 \mathrm{wt} \%$ to $7.7 \mathrm{wt} \%$ (Y-axis). The same narrow average cell size ranging between 275 and $300 \mu \mathrm{m}$ can be obtained using $6.8 \mathrm{wt} \% \mathrm{ADA}$ and a foaming time between $7.2 \mathrm{~min}$ and $11.6 \mathrm{~min}$. 


\section{Conclusions}

In this work, open-cell foamed PLA scaffolds were developed by compression molding and a three-level factorial Design of Experiments (DoE) was used to optimize the molding parameters (foaming time, mold opening temperature, and ADA blowing agent concentration) to reach a well-controlled open-cell structure. The minimum and maximum values of these three molding parameters were obtained using the CCD technique and their corresponding values were 5 and $15 \mathrm{~min}, 80^{\circ} \mathrm{C}$ and $120^{\circ} \mathrm{C}$, and 4.2 and $7.7 \mathrm{wt} \%$, respectively. The morphology of the developed foams was then studied by varying the three processing parameters between these limits. It was observed that, for a constant ADA concentration of $5.95 \mathrm{wt} \%$, when the mold opening temperature increased from $80^{\circ} \mathrm{C}$ to $120^{\circ} \mathrm{C}$, the average cell size was respectively increased from $136 \mu \mathrm{m}$ to $326 \mu \mathrm{m}$ because of the decrease in PLA matrix viscosity and consequently ADA gas diffusion increase inside the PLA matrix, leading to an increase in the formation and growth of cells. Also, under a constant mold opening temperature of $100^{\circ} \mathrm{C}$, an increase of the foaming time from $5 \mathrm{~min}$ to $15 \mathrm{~min}$ led to a respective increase of the average cell size from $209 \mu \mathrm{m}$ to $294 \mu \mathrm{m}$ because more time is given to the generated smaller bubbles to expand. Furthermore, for constant foaming time $(10 \mathrm{~min})$ and mold opening temperature $\left(100^{\circ} \mathrm{C}\right)$, an increase of ADA weight concentration from $4.2 \mathrm{wt} \%$ to $7.7 \mathrm{wt} \%$ led to an increase of the average cell size from $197 \mu \mathrm{m}$ to $317 \mu \mathrm{m}$ due to the higher gas concentration generated during ADA degradation.

Finally, we were able to show how the average cell size can be tailored by varying two of the three independent processing parameters, while maintaining the third one constant. For example, a narrow average cell size ranging between 275 and $300 \mu \mathrm{m}$ was obtained under a foaming time of $8 \mathrm{~min}$ and mold opening time values between $106^{\circ} \mathrm{C}$ and $112^{\circ} \mathrm{C}$, or a mold opening temperature of $109^{\circ} \mathrm{C}$ and foaming time values between 6 and $11 \mathrm{~min}$. This is important in the development of open-cell PLA scaffolds for bone regeneration for which the control of cell morphology is crucial for osteoblasts proliferation.

\section{Acknowledgements}

The authors acknowledge the financial support of the Natural Science and Engineering Research Council of Canada (NSERC) and the Research center for high performance polymer and composite systems (CREPEC).

\section{Conflicts of Interest}

The authors declare no conflicts of interest regarding the publication of this paper.

\section{References}

[1] Sivertsen, K. (2007) Polymer Foams. 3.063 Polymer Physics. https://ocw.mit.edu/courses/materials-science-and-engineering/3-063-polymer-phy 
sics-spring-2007/assignments/polymer foams.pdf

[2] Nofar, M. and Park, C.B. (2014) Poly(Lactic Acid) Foaming. Progress in Polymer Science, 39, 1721-1741. https://doi.org/10.1016/j.progpolymsci.2014.04.001

[3] Rhomie, L. and Heck, I. (2004) A Review of Commercially Used Chemical Foaming Agents for Thermoplastic Foams. Journal of Vinyl and Additive Technology, 4, 113-116. https://doi.org/10.1002/vnl.10027

[4] Jamshidian, M., Arab-Tehrany, E., Imran, M., Jacquot, M. and Desobry, S. (2010) Poly-Lactic Acid: Production, Applications, Nanocomposites, and Release Studies. Comprehensive Reviews in Food Science and Food Safety, 9, 552-571.

https://doi.org/10.1111/j.1541-4337.2010.00126.x

[5] Auras, R., Lim, L.T., Selke, S.E.M. and Tsuji, H. (2010) Poly(Lactic Acid): Synthesis, Structures, Properties, Processing, and Applications. John Wiley Sons Inc., Hoboken, 529. https://doi.org/10.1002/9780470649848

[6] Drumright, R.E., Gruber, P.R. and Henton, D.E. (2000) Polylactic Acid Technology. Advanced Materials, 12, 1841-1846.

https://doi.org/10.1002/1521-4095(200012)12:23<1841::AID-ADMA1841>3.0.CO;2E

[7] Savioli Lopes, M., Jardini, A.L. and Maciel Filho, R. (2012) Poly(Lactic Acid) Production for Tissue Engineering Applications. Procedia Engineering, 42, 1402-1413. https://doi.org/10.1016/j.proeng.2012.07.534

[8] Lasprilla, A.J., Martinez, G.A., Lunelli, B.H., Jardini, A.L. and Filho, R.M. (2012) Poly-Lactic Acid Synthesis for Application in Biomedical Devices-A Review. Biotechnology Advances, 30, 321-328. https://doi.org/10.1016/j.biotechadv.2011.06.019

[9] Mckeen, L. (2014) Plastics Used in Medical Devices. In: Modjarrad, K. and Ebnesajjad, S, Eds., Handbook of Polymer Applications in Medicine and Medical Devices, Elsevier, Amsterdam, 21-53. https://doi.org/10.1016/B978-0-323-22805-3.00003-7

[10] Sodergard, A. and Stolt, M. (2002) Properties of Lactic Acid Based Polymers and Their Correlation with Composition. Progress in Polymer Science, 27, 1123-1163. https://doi.org/10.1016/S0079-6700(02)00012-6

[11] Phiriyawirut, M., Sarapat, K., Sirima, S. and Prasertchol, A. (2019) Porous Electrospun Nanofiber from Biomass-Based Polyester Blends of Polylactic Acid and Polybutylene Succinate. Open Journal of Polym. Chemistry, 9, 1-15. https://doi.org/10.4236/ojpchem.2019.91001

[12] Tachibana, Y., et al. (2021) Environmental Biodegradability of Recombinant Structural Protein. Scientific Reports, 11, Article No. 242.

https://doi.org/10.1038/s41598-020-80114-6

[13] Rasal, R.M., Janorkar, A.V. and Hirta, D.E. (2010) Poly(Lactic Acid) Modifications. Progress in Polymer Science, 35, 338-356. https://doi.org/10.1016/j.progpolymsci.2009.12.003

[14] Sawyer, D.J. (2003) Bioprocessing-No Longer a Field of Dreams. Macromolecular Symposia, 201, 271-281. https://doi.org/10.1002/masy.200351130

[15] Auras, R., Harte, B. and Selke, S. (2004) An Overview of Polylactides as Packaging Materials. Macro-Molecular Bioscience, 4, 835-864.

https://doi.org/10.1002/mabi.200400043

[16] Khuri, A.I. (2003) Current Modeling and Design Issues in Response Surface Methodology: GLMs and Models with Block Effects. In: Khattree, R., Ed., Handbook of Statistics, Vol. 22, Elsevier, Amsterdam, 209-229.

https://doi.org/10.1016/S0169-7161(03)22008-3 
[17] Song, C., Kitamura, Y. and Li, S. (2014) Optimization of a Novel Cryogenic $\mathrm{CO}_{2}$ Capture Process by Response Surface Methodology (RSM). Journal of the Taiwan Institute of Chemical Engineers, 4, 1666-1676.

https://doi.org/10.1016/j.jtice.2013.12.009

[18] Prasanta, S. and Tapan, Kr.B. (2012) ANN Modelling of Fractal Dimension in Machining. In: Davim, J.P., Ed., Mechatronics and Manufacturing Engineering, Elsevier, Amsterdam, 159-226. https://doi.org/10.1533/9780857095893.159

[19] Lin, L., Lee, Y. and Park, H.E. (2021) Recycling and Rheology of Poly(Lactic Acid) (PLA) to Make Foams Using Supercritical Fluid. Physics of Fluids, 33, Article ID: 067119. https://doi.org/10.1063/5.0050649

[20] Tatibouet, J. and Gendron, R. (2005) Nucleation Mechanisms Investigated on Polystyrene/HFC-134 Mixtures. The 7 th International Conference on Blowing Agents and Foaming Processes, Stuttgart, 10-11 May 2005, 1-8.

https://books.google.ca/books/about/Blowing Agents and Foaming Processes 20 0.html?id=BVl-aENtK48C\&redir esc $=\mathrm{y}$

[21] Luo, Y., Zhang, J., Qi, R., Lu, J., Hu, X. and Jiang, P. (2013) Polylactide Foams Prepared by a Traditional Chemical Compression-Molding Method. Journal of Applied Polymer Science, 130, 330-337. https://doi.org/10.1002/app.39023

[22] Bhatnagar, N. and Srivatsan, T.S. (2009) Processing and Fabrication of Advanced Materials, XVII. International Publishing House Pvt. Ltd., New Delhi, Vol. 2, 728-729.

https://www.worldcat.org/title/processing-and-fabrication-of-advanced-materials-X vii/oclc/318093504

[23] Ospina, R. and Marmolejo-Ramos, F. (2019) Performance of Some Estimators of Relative Variability. Frontiers in Applied Mathematics and Statistics, 5, Article No. 43. https://doi.org/10.3389/fams.2019.00043

[24] Genawi, N.M., Ibrahim, M.H., El-Naas, M.H. and Alshaik, A.E. (2020) Chromium Removal from Tannery Wastewater by Electrocoagulation: Optimization and Sludge Characterization. MDPI Water, 12, 1374. https://doi.org/10.3390/w12051374 